African Crop Science Journal by African Crop Science Society is licensed under a Creative Commons Attribution 3.0 Uganda License. Based on a work at www.ajol.info/ and www.bioline.org.br/cs DOI: http://dx.doi.org/10.4314/acsj.v24i3.4

\title{
NUTRITIONAL PROFILE AND YIELD OF OYSTER MUSHROOM CULTIVATED ON SELECTED AGRICULTURAL WASTES
}

\author{
O.M. ADEDOKUN and M. GEORGE-DAVID \\ Department of Crop and Soil Science, Faculty of Agriculture, University of Port-Harcourt, PMB 5323, \\ Choba, Rivers State, Nigeria \\ Corresponding author: olutayo.adedokun@gmail.com
}

(Received 22 March, 2016; accepted 13 July, 2016)

\begin{abstract}
Research on mushroom production and products is gaining more grounds globally and in particular Nigeria. This study was carried out to determine nutritional relationship between the substrate used for cultivation and the fruiting body on each of the substrates. Agro-wastes, namely: palm (Elaeis guineensis) fruit shaft, plantain (Musa paradisiaca) leaves, sawdust and kenaf (Hibiscus cannabinus) stem, were assessed for suitability as substrates for cultivation of oyster mushroom (Pleurotus floridanus Singer). The spawn of the mushroom was used to inoculate each of the substrates, using a complete randomised design, with five replicates for each substrate. Results showed that all the substrates supported mycelia growth and development of fruiting bodies of the fungus. There were significant differences $(\mathrm{P}<0.05)$ among substrates in terms of number of days to complete mycelia run, with the least recorded in palm fruit shaft (25.20), and the highest in kenaf (32.40). Total

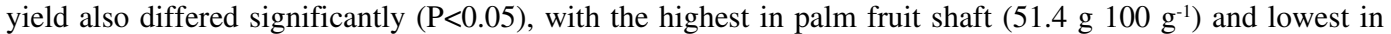

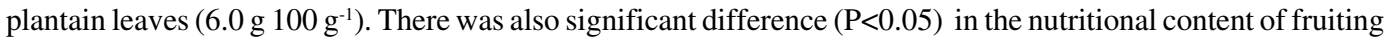

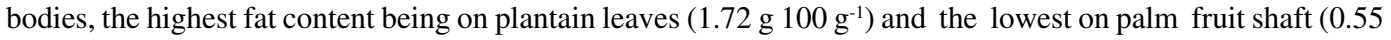

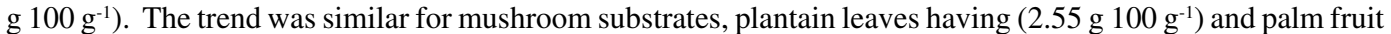

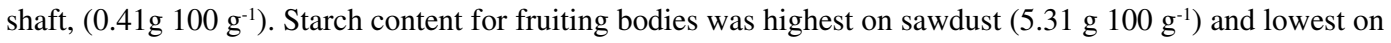

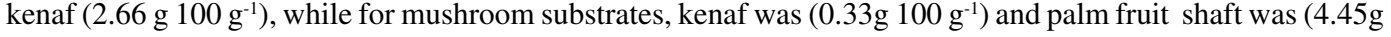
$\left.100 \mathrm{~g}^{-1}\right)$. There was a positive correlation $(\mathrm{r}=0.24)$ between the nutrient of fruiting bodies and that of the substrate on which it was cultivated.
\end{abstract}

Key Words: Kenaf, nutrient composition, mushroom fruiting body, mushroom substrate, Pleurotus floridanus

\section{RÉSUMÉ}

La production de la pleurote et produits dérivés fait de plus en plus objet de recherche dans le monde et surtout au Nigeria. La présente étude a été réalisé afin de determiner la relation nutritionnelle entre le substrat de culture utilisé et type de champignon obtenu. Des déchets agricols comme le faux regime de palmier (Elaeis guineensis), les feuilles du banaier plantain (Musa paradisiaca), la sciure et tige de kenaf (Hibiscus cannabinus), ont été évalués pour leur aptitude à servir de substrats de culture pour la pleurote (Pleurotus floridanus Singer). Les spores du champignon ont été utilisé pour inoculer chaque substrat. Les résultats ont montré que tous les substrats ont supporté la croissance du mycelium et le développement. Des differences significatives ont été observées entre les substrats $(\mathrm{P}<0.05)$, en ce qui concerne le nombre de jours nécessaires pour accomplir un cycle mycelien. Le cycle mycelien le plus court a été observé sur le faux régime de palmier (25.20), tandis que le cycle le plus long était observé sur le kenaf (32.40). Les rendements totaux varient d'un substrat à un autre $(\mathrm{P}<0.05)$;

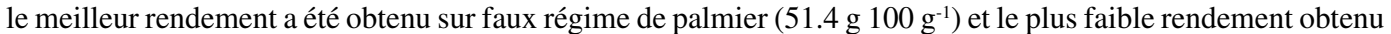

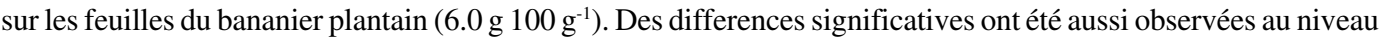


de la qualité nutrionelle du champignon $(\mathrm{P}<0.05)$. Les champignons de meilleures qualités nutritionnelles étaient

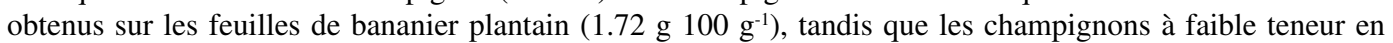

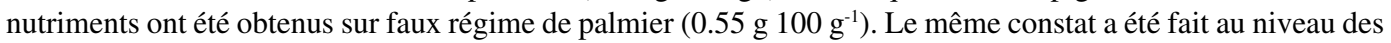

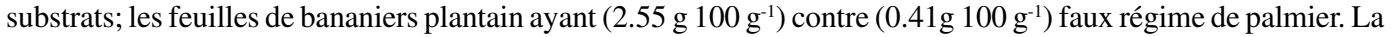

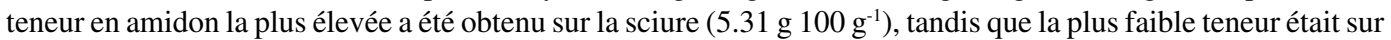

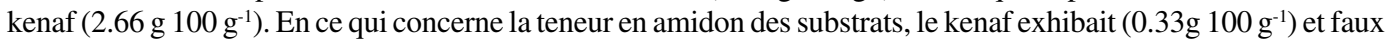

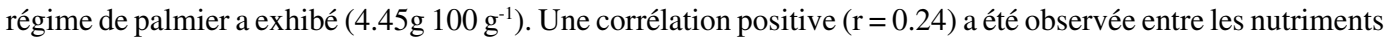
au sein du champignon et ceux du substrat sur lequel il est cultivé.

Mots Clés: Kenaf, composition nutritionelle, champignon, substrat de champignon, Pleurotus floridanus

\section{INTRODUCTION}

Mushrooms (Agaricus bisporus) are fungi that are heterotrophic and depend on other organisms for food. Oyster mushrooms belong to the species of Pleurotus, which are edible and have excellent flavour and taste (Shah et al., 2004). Mushrooms are recognised universally as food and are grown commercially in many parts of the world, including Nigeria. Mushroom substrate means a highly specific, nutrient-rich product prepared from selective organic and inorganic materials for the purpose of cultivating mushrooms. Substrates are both a physical support and a source of nutrients for the mushrooms needed to complete their life cycle (Diego et al., 2011). Production of substrate for mushroom growth is recognised as the most critical stage of cultivation because it has a dramatic effect on yield, quality and economic viability of the crop (Dhar, 1994).

Oyster mushrooms are known to have medicinal properties such as antitumor, antiviral, antineoplastic, antimutagenic, antilipemic, antioxidant (Yashvant et al., 2012) and contain good amount of protein, vitamins, minerals, low fat, crude fiber (Arun and Ramteke, 2010). Oyster mushroom cultivation is of economic importance in the area of agricultural waste recycling, animal feed, soil remediation, nutrition (Adedokun and Ataga, 2006; Emuh, 2010), economic use of land, income generating (Spore, 2006) and health.

Globally, huge volumes of wastes are generated through agricultural, forestry, industrial processes and their accumulation causes environmental pollution. Many agricultural wastes such as banana leaves, corn husk, corn cobs, palm fruit shaft, cotton wastes, sawdust, wheat straw, cassava peel, rice straw, cocoa pods and coconut husk have been used as substrates (growth medium) for mushrooms production (Adedokun et al., 2003; Amuneke et al., 2011; Stanley et al., 2011; Gume et al., 2013; Adedokun, 2014).

Sawdust is composed of tiny particles of wood produced when wood is sawed. Kenaf (Hibiscus cannabinus) is a fibre plant native to east-central Africa, where it has been grown for several thousand of years for food and fibre. It is a common wild plant of tropical and subtropical Africa and Asia and has been used as a source of textile fibre for such products as rope, twine, bagging and rugs (LeMahieu et al., 1991). Cultivation of mushroom on kenaf plant stem is novel in mushroom cultivation because to date there is little or no record of kenaf being used as substrate in mushroom cultivation. Dry plantain leaves are waste got from the plant Musa paradisiaca, which are abundant in Africa and are regarded by most individuals as garbage. Oil pam fruit shaft is a by-product after processing the fruit of the plant Elaeis guineensis. According to Sreekala et al. (1997), mesocarp fibres are left as waste material after oil extraction, creating great environmental problems.

The aim of this study was to examine the growth of Oyster mushrooms on selected agricultural wastes and investigate the relationship between the nutrient of the sporophores (fruiting bodies) and the substrate on which they were grown.

\section{MATERIALS AND METHODS}

This study was carried out at the mushroom unit of the University of Port-Harcourt Demonstration 
Farm, Choba Port-Harcourt in Rivers State, Nigeria. It lies at latitude $4^{\circ} 53 \mathrm{~N}$ and longitude $6^{\circ}$ $57 \mathrm{E}$.

Substrate source. Dry plantain banana leaves, kenaf stem, sawdust and palm fruit shaft were the materials used as substrates. Dry plantain leaves and kenaf stem were collected from the University of Port-Harcourt Demonstration Farm. Sawdust was collected from a mill at Rumuosi, nearby the University and palm fruit shaft was from oil mill at Aluu, nearby the University. These materials were selected because they are readily available as agricultural waste. The pure culture of the mushroom used for this study was that of PF001UPHNIG from the mushroom Bank of University of Port-Harcourt Mushroom Farm.

Substrate preparation. Substrate samples were sun-dried and analysed to determine nutrient status prior to mushroom cultivation. Four agricultural wastes: palm fruit shaft, dry plantain leaves, kenaf and sawdust were used as test substrates. Each substrate was mixed in a ratio of $80 \%$ dry substrate, $15 \%$ wheat bran and $5 \%$ lime with 150-200 ml of water, depending on substrate, but ensuring no water logs. The method used for mushroom cultivation was that of modified Stamets (2000). Five hundred grammes of each material was packed and sealed in polyethylene bags, and sterilised and inoculated with $10 \%$ (w/ w) of spawn in a sterile environment and later transferred to an incubation room for ramification. Each substrate was replicated five times.

Data collection. Mycelia run were assessed by recording the number of days mushroom mycelia fully colonised a substrate bag.

Fruiting and harvesting. Substrate bags, when fully colonised with mycelia, were transferred to the fruiting room and opened to initiate fruiting, through sprinkling of water on the bags. Sporophores (fruiting bodies) were harvested by hand-twisting, weighed with electronic digital balance and dried in a fabricated solar dryer of temperature $48 \pm 2^{\circ} \mathrm{C}$ for 4 days. When constant weight was observed, the dried samples were kept in air-tight envelops and taken to the laboratory for analysis.
After harvesting, the test substrates as well as fruiting bodies, were analysed for total starch and total fat content, determined by the amyloglucosidase/ $\alpha$-amylase method, with UV-Visible spectrophotometry (McCleary et al., 1997). Total fat was analysed using the chloroform/methanol gravimetric method according to AOAC Official Method 983.23. (1990).

Data obtained were analysed using analysis of variance (ANOVA) procedure of SAS statistical software package (2001).

\section{RESULTS}

Mycelia run on various substrates. Pleurotus floridanus cultivated on test substrates colonised all the substrates used (Plate 1). However, the rate of colonisation was different among substrates. Substrate colonisation by mycelia was significantly superior in palm fruit shaft and least in Kenaf. When compared with palm fruit shaft, the percentage change for days to myceliarun of other substrates are: 115, 127 and 128\% for sawdust, plantain leaves and kenaf, respectively. Palm fruit shaft substrate differed significantly $(\mathrm{P}<0.05)$ from kenaf and plantain leaves, but not sawdust.

Mushroom yield. Table 2 displays yield of Oyster mushroom. Overall, the highest total yield was obtained from palm fruit shaft. There was significant $(\mathrm{P}<0.05)$ difference between the yield of palm fruit shaft and other substrates .However, there was no significance different $(\mathrm{P}>0.05)$ between the yield of kenaf and sawdust. Furthermore the yield of Oyster mushroom between flushes was significantly different $(\mathrm{P}<0.05)$, the first yield being greater than the subsequent flush.

TABLE 1. Mycelia run on substrates

\begin{tabular}{lc}
\hline Substrates & Mycelia run (days) \\
\hline Palm fruit shaft & 25.20 \\
Kenaf & 32.40 \\
Sawdust & 29.00 \\
Plantain leaves & 32.20 \\
& \\
LSD $(0.05)$ & 4.63 \\
\hline
\end{tabular}



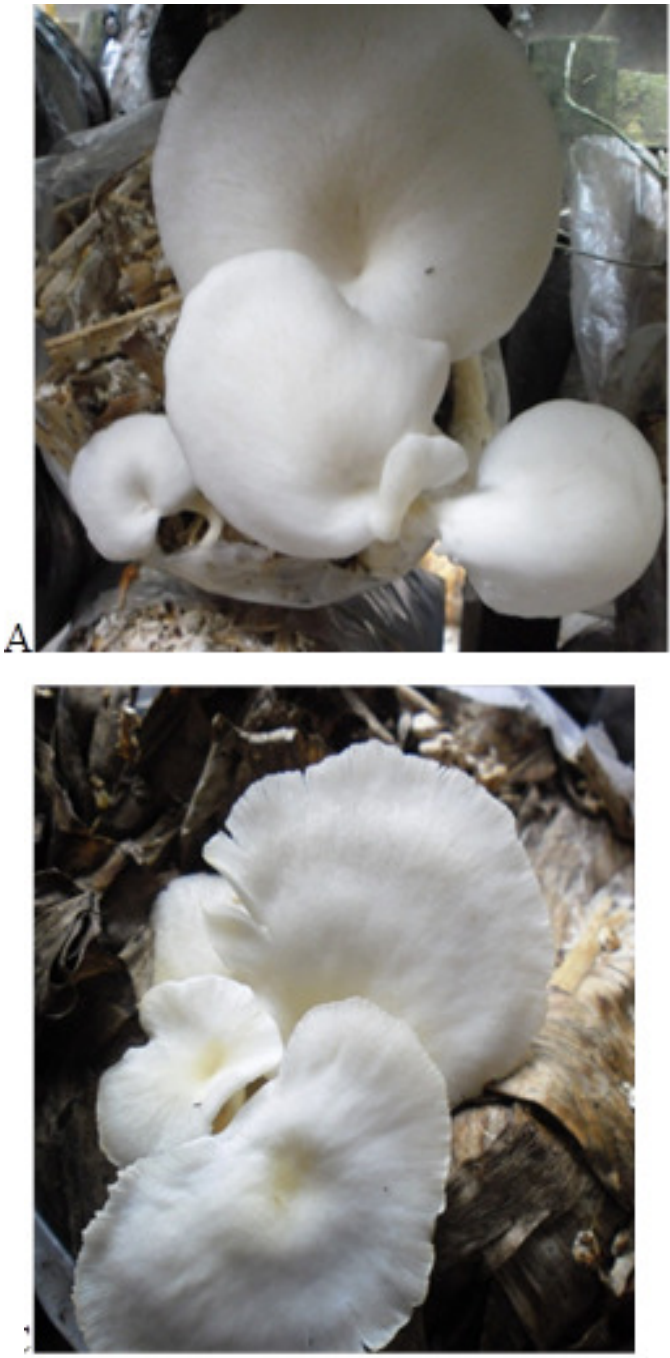
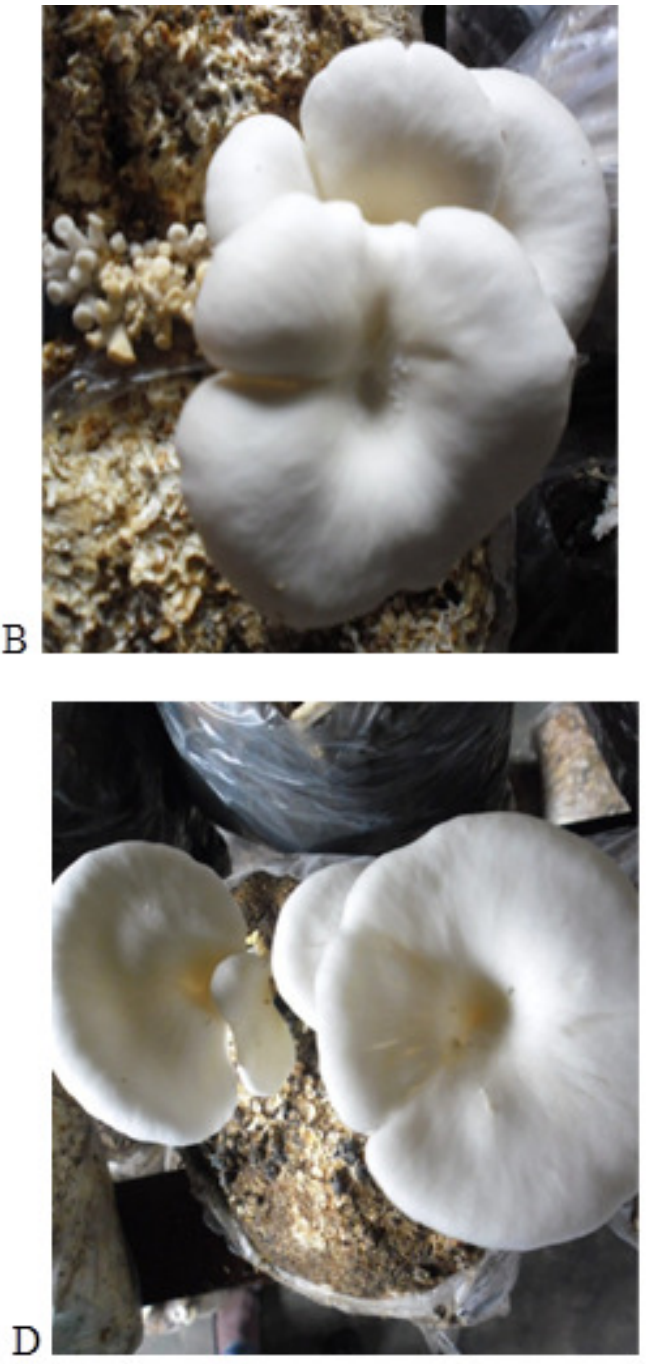

Plate 1. Fruiting bodies of Pleurotus floridanus cultivated on different substrates. $A=$ kenaf, $B=$ palm fruit shaft, $C=$ plantain leaves, $\mathrm{D}=$ sawdust.

TABLE 2. Total yield of mushroom on different substrates

\begin{tabular}{lrrr}
\hline Substrate & \multicolumn{2}{c}{ Flushes $\left(100 \mathrm{~g}^{-1}\right)$} & Total $\left(100 \mathrm{~g}^{-1}\right)$ \\
\cline { 2 - 3 } & $1^{\text {st }}$ & $2^{\text {nd }}$ & \\
\hline Palm fruit shaft & 37.2 & 14.2 & 51.4 \\
Kenaf & 22.6 & 10.1 & 32.7 \\
Sawdust & 22.9 & 11.3 & 34.2 \\
Plantain leaves & 4.8 & 1.2 & 6.0 \\
LSD $(0.05)$ & 8.92 & 4.23 & \\
\hline
\end{tabular}


TABLE 3. Nutritional contents of fruiting bodies and substrates

\begin{tabular}{lccccc}
\hline Substrate & \multicolumn{2}{c}{ Starch content $\left(100 \mathrm{~g}^{-1}\right)$} & & \multicolumn{2}{c}{ Fat content $\left(100 \mathrm{~g}^{-1}\right)$} \\
\cline { 2 - 3 } \cline { 5 - 6 } & Substrate before study & Mushroom & & Substrate before study & Mushroom \\
\hline Palm fruit shaft & 4.45 & 4.56 & & 0.41 & 0.55 \\
Kenaf & 0.33 & 2.66 & & 1.18 & 1.01 \\
Sawdust & 2.81 & 5.31 & & 1.09 & 1.01 \\
Plantain leaves & 2.15 & 4.49 & & 2.55 & 1.72 \\
$\operatorname{LSD}(0.05)$ & 0.28 & 1.01 & & 0.74 & 0.87 \\
\hline
\end{tabular}

Nutritional contents. The nutritional contents of mushroom and substrate samples are as presented in Table 3 . The fat and starch content varied from one substrate to another, the fat content was lower than the starch content for both mushroom and substrate. The fat content of the mushroom was proportional to that of the substrate; the lowest being in palm fruit shaft and the highest in plantain leaves. There was significant difference $(\mathrm{P}<0.05)$ among substrates as well as the mushrooms harvested from them. Starch content of the mushroom compared well with substrates, except for sawdust. Kenaf had the lowest starch content both for substrate and mushroom. The highest substrate starch content was recorded in palm fruit shaft whereas starch content for mushroom was highest on sawdust substrate. There was significant difference $(\mathrm{P}<0.05)$ for starch content among the substrates; however, mushrooms harvested on kenaf were significantly different from those harvested on other substrates, which are not significantly different from one another.

\section{DISCUSSION}

Mycelia- run and mushroom yield on substrates. Three substrates used in this study compared well with sawdust in mycelia run, yield and nutritional content (Tables 1, 2 and 3) which is widely used for mushroom production. Palm fruit shaft substrate scoring best. Cultivation of mushroom on kenaf plant stem is novel in mushroom cultivation because todate there is little or no record of kenaf being used as substrate in mushroom cultivation. This may be harnessed for cultivation in areas where it occurs in abundance. The fact that all the agricultural substrates used supported growth of mushroom mycelia and fruiting bodies could be due to the ligno-cellulosic substances present in the test substrates. Various researchers have reported the bio-conversion of ligno-cellulosic residues through cultivation of mushrooms (Onyango et al., 2011; Adedokun, 2014). Utilisation of these ligno-cellulosic agricultural residues for mushroom production could obviate a number of environmental concerns resulting from disposal of the materials as wastes.

The full mycelia colonisation, which was attained at different times (Table 1) by each substrate suggests that complete ramification of any substrate by mycelia of mushrooms is substrate dependent. Since the quantity of the substrates was similar, the variations observed in the colonisation of mushroom mycelia could be attributed to differences in bio-chemical composition, such as lignin, cellulose, starch, and other essential plant components. Findings in this research agree with the work of several researchers (Shah et al., 2004; Adebayo et al., 2009; Kymberly, 2010); but not with Onuoha et al. (2009) who reported no colonisation of substrates from oil palm fibre.

Mushroom growth on palm fruit shaft, plantain leaves and kenaf is good news in Africa because it is an innovative value addition to byeproducts to which little or no value would ordinarily have been attached. The quantity of wheat bran supplement may be increased to boost yield (Adedokun et al., 2003; Oei, 2003). The sporophores of oyster mushroom were harvested in two flushes and the maximum yield was obtained in first, which was greater than the 
second flush. The reduction in yield could have been caused by the depletion of nutrients from substrates (Amuneke et al., 2011).

\section{Nutritional composition of mushroom substrates} and fruiting bodies. The results on nutritional composition of substrates and fruiting bodies agree with those of Silva et al. (2002) who reported that although, there may be correlation in chemical composition of mushroom and substrate used for cultivation, chemical composition of mushroom does not correspond to the chemical composition of substrate. The findings of Khan et al. (2008) reported that the nutritional composition of oyster mushroom differs significantly when grown in different substrates. Other works have also reported varied amount of fat contents in oyster mushrooms grown on different substrates (Vimla, 2009). The relatively low content of starch and fat supports other research claims that mushroom are low carbohydrate, low in fat vegetables (Chang and Mshigeni, 2001).

\section{REFERENCES}

Adebayo, J.G., Banjo, N.O. and Abikoye, E.T. 2009. Evaluation of yield of oyster mushroom (Pleurotus pulmonarius) grown on cotton waste and cassava peel. African Journal of Biotechnology 8(2):215-218.

Adedokun, O.M. 2014. Oyster mushroom: Exploration of additional agro-waste Substrates in Nigeria. International Journal of Agricultural Research 9 (1):55-59.

Adedokun, O.M., Ayodele, V.I. and Fasidi, I.O. 2003. Spawn production and growth of Pleurotus tuber regium (fries) singers on agricultural wastes. Bioscience Research Communications 15 (6): 437 - 444

Adedokun, O.M. and Ataga, A.E. 2006. Effects of crude oil and oil products on growth of some edible mushrooms. Journal of Applied Science and Environmental Management 10 (2): 91 - 93.

Amuneke, E.H., Dike, K.S. and Ogbulie, J.N. 2011. Cultivation of Pleurotus ostreatus: An edible mushroom from agrobase waste products. Journal of Microbiology and Biotechnology Research 1:1-14.
Arun, I. and Ramteke, A. 2010. Studies on cultivation and biological efficiency of mushrooms grown on different agro-residues. Dunãrea de Jos" University - Galapi. Innovative Romanian Food Biotechnology 6:25-28.

AOAC Official Methods of Analysis, Method 983.23. 1990. Association of Official Analytical Chemists: $15^{\text {th }}$ Ed, Arlington, VA.

Chang, S.T. and Mshigeni, K.E. 2001. Mushrooms and human health: Their growing significance as potent dietary supplements. The University of Namibia,Windhoek. pp.1-70.

Dhar, B.L. 1994. Mushroom composting for Agaricus bisporus/bitorquis. In: Nair, M.C. (Ed.). Advances in Mushroom biotechnology, Jophpur: Scientific Publishers. pp. 84-90.

Emuh, F.N. 2010. Mushroom as a purifier of crude oil polluted soil. International Journal of Science and Nature 1(2): 127-132.

Gume, B., Muleta, D. and Abate, D. 2013. Evaluation of locally available substrates for cultivation of some edible mushrooms. African Journal of Microbiology Research 7:2228-2237.

Khan Asaduzzaman, Md., Tania Mousumi, S.M. Ruhul Amin, Nadia Alam and Nazim Uddin Md. 2008. An investigation on the nutritional composition of mushroom (Pleurotus florida) cultivated on different substrates. Bangladesh Journal on Mushroom 2(2):1723.

Kymberly, R.D. 2010. Vigor, sex and woody substrates: Lessons from the cultivation of Pleurotus Ostreatus . University of Wisconsin-Green Bay Solid Waste Research Program.

LeMahieu,P.J.,Oplinger, E.S and Putnam D.H. 1991. Kenaf an alternative field crops manual. WisconsinAgriculturalextensionservice. http://bioweb.sungrant.org/Technical/ Biomass+Resources/Agricultural+ Resources/New+Crops/Non-Wood+Fiber+ Crops/Kenaf/ (Accessed April 29, 2014).

McCleary, B.V., Gibson, T. S. and Mugford, D. C. 1997. Measurement of total starch in cereal products by amyloglucosidase - $\alpha$ - amylase method: Collaborative study. Journal of Association of Official Analytical Chemists International 80: 571-579. 
Oei, P. 2003. Mycelia sell this fascinating mushroom growing book: Mushroom Cultivation, Third Edition, Backhuys Publishers, Leiden, The Netherlands. 429pp.

Onuoha, C.I., Ukaulor, U. and Onuoha C.B. 2009. Cultivation of Pleurotus pulmonarius (mushroom) using some agro waste materials. Agricultural Journal 4(2):109-112.

Onyango, B.O., Palapala, V.A., Arama, P.F., Wagai, S.O. and Gichimu, B.M. 2011. Suitability of selected supplemented substrates for cultivation of Kenyan native wood ear mushrooms (Auricularia auricula). America Journal of Food Technology 6: 395-403.

SAS, 2002. SAS for Windows Release 9.1 (Statistical Analysis Systems Institute Inc. Cary, NC, USA).

Shah, Z.A, Ashraf, M. and Ishtiaq, M.C. 2004. Comparative study on cultivation and yield performance of Oyster mushroom (Pleurotus ostreatus) on different substrates (wheat straw, leaves, saw dust). Pakistan Journal of Nutrition 3(3):158-160.

Silva, S.O., Gomes da Costa, S.M. and Clemente, E. 2002. Chemical composition of Pleurotus pulmonarius (Fr.) Quel., Substrates and residue after cultivation. Brazilian Archives of Biology and Technology 45(4): 531-535.

Sreekala, M.S., Kumaran, M.G. and Thomas, S. 1997. Oil palm fibres: Morphology, chemical composition, surface modification, and mechanical properties. Journal of Applied Polymer Science 66(5): 821-835.

Stamets, P. 2000. Growing gourmet and medicinal mushrooms, ten speed press, California. 574pp.

Stanley, H.O., Umolo, E.A. and Stanley, C.N. 2011. Cultivation of oyster mushroom (Pleurotus pulmonarius) on amended corncob substrate. Agriculture and Biology Journal of North America 2(8):1239 - 1243.

Spore. 2006. Information for Agricultural development in ACP countries. CTA Issue, 124 (August).

Vimla Dunkwal and Sudesh Jood. 2009. Effect of substrates on nutrient composition of oyster mushroom (Pleurotus sajor caju). Journal of Dairying, Food and Home Sciences 28 (2):132-136.

Yashvant, P., Ram, N. and Singh, V.K. 2012. Medicinal properties of Pleurotus Species (Oyster mushroom): A Review. World Journal of Fungal and Plant Biology 3(1): 01-12.

Zied, D.C., Savoie, J. and Pardo-Giménez, A. 2011. Soybean the main nitrogen source in cultivation substrates of edible and medicinal mushrooms. Soybean and nutrition. Hany El-Shemy (Ed.). ISBN: 978-953-307-536-5, InTech. http://www.intechopen.com/books/ soybean-and-nutrition/soybean-the-mainnitrogen-source-in-cultivation-substrates-ofedible-and-medicinal-mushrooms. 